\title{
CHANGES IN THE ANTIGENIC PROPERTIES OF CONNECTIVE TISSUE IN THE SKIN OF EMBRYONIC RATS DURING DEVELOPMENT
}

\author{
BY \\ D. G. SCOTT AND N. R. ROWELL \\ Department of Dermatology, University of Leeds
}

In studies primarily concerned with the antigenic constitution of capillaries in histologically mature and immature renal glomeruli, it was found that fluorescein-anti-adult rat renal connective tissues antisera lost some, but not all of their anti-connective tissue reactivity on absorption with embryonic connective tissue, obtained from rat embryos measuring up to $1.0 \mathrm{~cm}$. in crown to rump length (Scott and Rowell, 1967). This observation raised the possibility that there might be a partial rather than complete overlap in antigenic specificity between connective tissues of the adult and embryonic rat. The present studies were undertaken to explore this possibility. They concern the antitissue specificities of antisera raised in rabbits against (a) adult rat renal connective tissue; $(b)$ connective tissues obtained from rat embryos measuring more than 0.7 and less than $1.5 \mathrm{~cm}$. in crown to rump length.

\section{Material and Methods}

Globulin fractions of rabbit anti-adult rat renal connective tissue (anti-adult) and of rabbit anti-embryonic rat connective tissue (anti-embryo) antisera were conjugated with fluorescein isothiocyanate. The distribution of specific fluorescence produced by the one conjugate in direct staining, cross-inhibition and cross-absorption experiments, was compared with that produced by the other in the kidneys of adult rats and in the skin of two groups of rat embryos. One of these groups was made up of six paternally, but not maternally, related embryos, measuring from 1.0 to $1.5 \mathrm{~cm}$. in crown to rump length. The second group included eight maternally unrelated embryos, measuring more than 1.5 but less than $2.0 \mathrm{~cm}$. in crown to rump length; six of these 1.5 to $2.0 \mathrm{~cm}$. embryos were paternally related to members of the 1.0 to $1.5 \mathrm{~cm}$. group, while two were not so related.

\section{Preparation of Antigens}

Adult Rat Renal Connective Tissue.-This was prepared from the kidneys of 24 adult rats. The kidneys were finely sliced and passed successively through 50, 80, 100, 120 , and 140 mesh monel woven wire gauze sieves. Renal glomeruli were separated from material passing the 140 mesh sieve by differential sedimentation in chilled $0.05 \mathrm{M} \mathrm{PO}_{4}$ buffered saline $\mathrm{pH} 8.6$ (Hill and Cruickshank, 1953; Krakower and Greenspon, 1951). Material retained by each sieve was harvested, suspended in $\mathrm{pH} 8 \cdot 6$ buffered saline, and rendered relatively free of cells by repeated homogenization and centrifugation. The cellfree fibrillar material so obtained was fragmented in a Griffith tube, packed by centrifugation, and adjusted to a 40 per cent. $\mathrm{v} / \mathrm{v}$ concentration in $0.01 \mathrm{M}$ phosphate buffered saline $\mathrm{pH} 7 \cdot 2$ to $7 \cdot 4$. To the renal fibrillar tissue was then added an equal volume of a $\mathbf{4 0}$ per cent. $\mathrm{v} / \mathrm{v}$ suspension of packed homogenized glomeruli in $\mathrm{pH}$ $7 \cdot 2$ buffered saline.

\section{Embryonic Tissue}

(a) IMMUNizing ANTIGEN.-Anti-embryonic connective tissue antisera were raised against cell-free fibrillar tissues obtained by methods already described (Scott and Rowell, 1967) from rat embryos measuring more than 0.7 but less than $1.5 \mathrm{~cm}$. in crown to rump length.

(b) Cross-Absorbing Antigen.-Material used for the cross-absorption of the fluorescein-anti-adult rat renal connective tissue conjugates was obtained from rat embryos measuring up to $0.7 \mathrm{~cm}$. in crown to rump length. Quick-frozen decapitated embryos, which had been stored at $-15^{\circ} \mathrm{C}$, were allowed to thaw out completely. They were then homogenized briefly in $\mathrm{pH} 8.6$ buffered saline in an M.S.E. homogenizer and fragmented further in a glass tissue grinder. The tissue suspension so obtained was packed by high speed centrifugation $\left(18,000\right.$ r.p.m. at $5^{\circ} \mathrm{C}$. for 20 minutes), re-suspended in pH $7 \cdot 2$ buffered saline to give a 5 per cent. $\mathrm{v} / \mathrm{v}$ suspension and stored at $-15^{\circ} \mathrm{C}$. in $3 \mathrm{ml}$. volumes. 


\section{Preparation of Antisera}

Antigens were administered to rabbits as a 10 per cent. $\mathrm{v} / \mathrm{v}$ suspension in saline and as a 10 per cent. $\mathrm{v} / \mathrm{v}$ suspension in Freund's complete or incomplete adjuvant. Suspensions of antigen in saline were injected intra-peritoneally in $1 \mathrm{ml}$. doses. The antigen-adjuvant emulsions were injected subcutaneously in $0.25 \mathrm{ml}$. amounts into two or four limbs or into separate sites on the back of animals on a single occasion. Animals received one to four 4-week courses of immunizing injections. In the first week of such a course they received $4 \times 0.25 \mathrm{ml}$. antigen in complete adjuvant. During the next three weeks they received either $1.5 \mathrm{ml}$. antigen in incomplete adjuvant or $12 \mathrm{ml}$. antigen in saline (Table I). The animals were then rested for a month before being re-immunized.

TABLE I

IMMUNIZATION SCHEDULES

\begin{tabular}{|c|c|c|c|}
\hline \multirow{2}{*}{$\begin{array}{c}\text { Rabbit } \\
\text { No. }\end{array}$} & \multicolumn{2}{|c|}{$\begin{array}{l}\text { Number of 4-week courses of immunizing } \\
\text { injections each course comprising: } \\
\text { Antigen in complete adjuvant (One divided } \\
2 \mathrm{ml} \text {. dose) followed by antigen in } \\
\text { (A) or (B) }\end{array}$} & \multirow{2}{*}{ Antigen } \\
\hline & $\begin{array}{c}\text { (A) } \\
\text { Incomplete Adjuvant } \\
2 \times 0.25 \text { ml./week } \times \\
3 \text { weeks }\end{array}$ & $\begin{array}{c}\text { (B) } \\
4 \times 1 \text { ml. } / \text { week } \\
3 \text { weeks }\end{array} \times$ & \\
\hline $\begin{array}{l}1 \\
2 \\
3\end{array}$ & $\begin{array}{l}3 \\
1 \\
-\end{array}$ & $\begin{array}{l}\overline{2} \\
2\end{array}$ & $\begin{array}{l}\text { Adult rat } \\
\text { renal con- } \\
\text { nective } \\
\text { tissue }\end{array}$ \\
\hline $\begin{array}{l}4 \\
5 \\
6 \\
7\end{array}$ & $\begin{array}{l}3 \\
1 \\
2 \\
1\end{array}$ & $\begin{array}{l}\overline{2} \\
1 \\
-\end{array}$ & $\begin{array}{l}\text { Embryonic } \\
\text { rat } \\
\text { connective } \\
\text { tissue }\end{array}$ \\
\hline
\end{tabular}

Preparation of Conjugates and Tissue Sections

Animals were bled from an ear vein on the 7 th, 10th, and 12th day, after the completion of a course of immunizing injections. Serum harvested from these bleedings was pooled. Crude globulin fractions of the antisera so obtained were conjugated with fluorescein isothiocyanate. Conjugates of like specificity were later pooled together and pools were similarly prepared from unlabelled anti-adult and anti-embryo globulins.

Methods used in the labelling of globulins with fluorescein isothiocyanate, in the preparation of conjugates for use as immuno-histological staining reagents, and in the preparation of tissue sections have already been described (Scott and Rowell, 1967).

\section{Preparation of Cross-Absorbed Conjugates}

The cross-absorbed F-anti-adult $\times$ embryo conjugate was prepared by repeatedly absorbing $3 \mathrm{ml}$. fluoresceinanti-adult rat renal connective tissue (F-anti-adult) conjugate with the high speed sediment obtained from $3 \mathrm{ml}$. of a 5 per cent. suspension of the embryonic cross-absorbing antigen.

The cross-absorbed F-anti-embryo $\times$ adult conjugate was similarly prepared by absorbing $3 \mathrm{ml}$. fluoresceinanti-embryonic rat connective tissue (F-anti-embryo) conjugate with the high speed sediment obtained from $3 \mathrm{ml}$. of a 5 per cent. suspension of the adult rat renal connective tissue antigen.
Before cross-absorption the $F$-anti-adult conjugate produced specific staining of dermal and other connective tissues in sections from embryos of all ages. The process of cross-absorption was followed immuno-histologically and was carried to the point where the cross-absorbed F-anti-adult $\times$ embryo conjugate no longer produced detectable staining of dermal connective tissues in sections prepared from rat embryos measuring up to $0.7 \mathrm{~cm}$. in crown to rump length.

In the case of the F-anti-embryo conjugate, crossabsorption was carried to the point where the conjugate was found to have lost its reactivity for connective tissues in the kidneys of adult rats.

Before their use in the staining experiments described below, cross-absorbed conjugates were adjusted to a volume of $2.75 \mathrm{ml}$. by preliminary over-concentration, using Sephadex G25, and subsequent dilution with $0 \cdot 01 \mathrm{M} \mathrm{PO}{ }_{4}$ buffered saline, $\mathrm{pH} 7 \cdot 2$.

\section{Staining Experiments}

Three types of staining experiments were performed; direct staining, cross-inhibition, and cross-absorption (Table II). In these experiments sections were pretreated with a measured volume of unlabelled globulin for 3 hours at room temperature, and for 15 hours at $4^{\circ} \mathrm{C}$. To the unlabelled globulin was then added an equal volume of an anti-rat connective tissue conjugate and incubation was continued for a further $1 \frac{1}{2}$ hours at room temperature.

Direct Staining Experiments.-Sections were pretreated with unlabelled normal rabbit globulin and then incubated with a mixture containing equal parts of unlabelled normal rabbit globulin and one or other of the anti-tissue conjugates; fluorescein-anti-adult rat renal connective tissue (F-anti-adult) or fluorescein-antiembryonic rat connective tissue (F-anti-embryo).

Tests of the specificity of staining (direct inhibition experiments-Table II, opposite) were routinely run in parallel with direct staining experiments. In these tests anti-tissue conjugates were reacted with sections in the presence of the corresponding unlabelled anti-tissue globulins.

Cross-inhibition Experiments.-The F-anti-embryo conjugate was reacted with sections in the presence of unlabelled anti-adult globulins. The inhibitory activity of unlabelled anti-embryo globulins towards the F-antiadult conjugate was tested similarly.

Cross-absorption Experiments.-These were performed in the same way as direct staining experiments, but were based upon the use of the cross-absorbed F-anti-adult $\times$ embryo and $\mathrm{F}$-anti-embryo $\times$ adult conjugates.

\section{Observations}

\section{Direct Staining Experiments}

Observations made in this group of experiments are summarized in Tables III and IV (opposite). 
TABLE II

STAINING EXPERIMENTS

\begin{tabular}{|c|c|c|c|c|c|c|c|}
\hline \multicolumn{6}{|c|}{ Experiment } & \multirow{2}{*}{$\begin{array}{c}\text { Pretreatment } \\
\begin{array}{c}\text { Unlabelled Globulin } \\
3 \text { hrs at } 20^{\circ} \mathrm{C} \text {. and } 15 \text { hrs at } 4^{\circ} \mathrm{C} .\end{array} \\
\begin{array}{l}\text { Normal rabbit globulin } \\
\text { Normal rabbit globulin }\end{array}\end{array}$} & \multirow{2}{*}{$\begin{array}{l}\begin{array}{c}\text { Staining } \\
\text { Unlabelled Globulin } \\
+ \text { Conjugate } 1 \frac{1}{2} \text { hrs at } 20^{\circ} \mathrm{C} .\end{array} \\
\text { anti-adult } \\
\text { inti-embryo }\end{array}$} \\
\hline Direct Staining & $\cdots$ & $\cdots$ & $\cdots$ & $\cdots$ & . & & \\
\hline Direct Inhibition & $\ldots$ & $\cdots$ & $\cdots$ & $\cdots$ & . & $\begin{array}{l}\text { Anti-adult } \\
\text { Anti-embryo }\end{array}$ & $\begin{array}{l}\text { F-anti-adult } \\
\text { F-anti-embryo }\end{array}$ \\
\hline Cross-Inhibition & . & $\cdots$ & $\cdots$ & $\cdots$ & $\cdots$ & $\begin{array}{l}\text { Anti-embryo } \\
\text { Anti-adult }\end{array}$ & $\begin{array}{l}\text { F-anti-adult } \\
\text { F-anti-embryo }\end{array}$ \\
\hline Cross-Absorption & & $\cdots$ & $\cdots$ & $\cdots$ & . & $\begin{array}{l}\text { Normal rabbit globulin } \\
\text { Normal rabbit globulin }\end{array}$ & $\begin{array}{l}\text { Anti-adult } \times \text { embryonic CT } \\
\text { Anti-embryonic } \times \text { adult } \text { CT }\end{array}$ \\
\hline Cross-Absorption & n-inh & ition & $\cdots$ & . & $\cdots$ & $\begin{array}{l}\text { Anti-adult } \times \text { embryonic CT } \\
\text { Anti-adult } \times \text { adult } C T\end{array}$ & $\begin{array}{l}\text { F-anti-adult } \\
\text { F-anti-embryo }\end{array}$ \\
\hline
\end{tabular}

Anti-adult $=$ Unlabelled anti-Adult rat renal connective tissue. F-anti-adult $=$ Fluorescein anti-Adult rat renal connective tissue Anti-embryo = Unlabelled anti-Embryonic rat connective tissue. F-anti-embryo $=$ Fluorescein anti-Embryonic rat connective tissue.
CT = Connective tissue antigen.

Sections were pre-treated with a measured volume of unlabelled globulin and then stained with a mixture containing equal parts of labelled and unlabelled globulin.

TABLE III

ADULT RAT KIDNEY

\begin{tabular}{|c|c|c|c|c|c|c|}
\hline \multirow{2}{*}{ Tissue } & \multirow{2}{*}{ Media of Arteries } & \multicolumn{2}{|c|}{ Glomeruli } & \multirow{2}{*}{ B.M. Tubules } & \multirow{2}{*}{ Interstitial } & \multirow{2}{*}{$\underset{\text { Experiment }}{\text { Staining }}$} \\
\hline & & B.M. Capillaries & Epithelial Cells & & & \\
\hline NRG + F-v-Adult & + & + & + & + & + & \multirow{2}{*}{ Direct Staining } \\
\hline NRG + F-v-Embryo & 一 & - & + & $(+)$ & + & \\
\hline v-Adult + F-v-Adult & - & - & - & - & - & \multirow{2}{*}{ Direct Inhibition } \\
\hline v-Embryo + F-v-Embryo & - & - & - & - & - & \\
\hline v-Embryo + F-v-Adult & + & + & - & $(+)$ & - & \multirow{2}{*}{ Cross-Inhibition } \\
\hline v-Adult + F-v-Embryo & 一 & - & - & - & - & \\
\hline F-v-Adult $\times$ E.c.t. & + & + & - & $(+)$ & - & \multirow{2}{*}{ Cross-Absorption } \\
\hline F-v-Embryo $\times$ A.c.t. & - & - & - & - & - & \\
\hline
\end{tabular}

NRG Normal rabbit globulin. $\quad x \quad$ Absorbed with.

$\begin{array}{lll}\text { Normal rabbit globulin. } & \text { Absorbed with. } \\ \text { Unlabelled anti-Adult rat renal connective tissue. A.c.t. Adult renal connective tissue. }\end{array}$

F-v-Adult Fluorescein anti-Adult rat renal connective tissue. E.c.t. Embryonic connective tissue.

v-Embryo Unlabelled anti-Embryonic rat connective tissue. $(+)$ Peritubular staining designated by this symbol differed morphologi-

F-v-Embryo Fluorescein anti-Embryonic rat connective tissue.

TABLE IV

cally from that seen after F-v-Adult direct staining experiments (see text).

EMBRYONIC RAT SKIN

\begin{tabular}{|c|c|c|c|c|c|c|c|c|c|}
\hline \multicolumn{10}{|c|}{ EMBRYONIC RAT SKIN } \\
\hline \multirow{3}{*}{ Embryo No. } & \multicolumn{8}{|c|}{ Staining Experiments } & \multirow{3}{*}{$\begin{array}{c}\text { Tissue } \\
\text { Components }\end{array}$} \\
\hline & \multicolumn{2}{|c|}{$\begin{array}{c}\text { Direct } \\
\text { Staining }\end{array}$} & \multicolumn{2}{|c|}{$\begin{array}{c}\text { Cross- } \\
\text { Inhibition }\end{array}$} & \multicolumn{2}{|c|}{$\begin{array}{c}\text { Cross- } \\
\text { Absorption }\end{array}$} & \multicolumn{2}{|c|}{$\begin{array}{c}\text { Direct } \\
\text { Inhibition }\end{array}$} & \\
\hline & $\begin{array}{c}\text { NRG } \\
+ \\
\text { F-aA }\end{array}$ & $\begin{array}{c}\text { NRG } \\
+ \\
\text { F-aE }\end{array}$ & $\begin{array}{c}\mathbf{a E} \\
+ \\
\mathbf{F}-\mathbf{a A}\end{array}$ & $\begin{array}{c}\mathbf{a A} \\
+ \\
\mathbf{F}-\mathbf{a E}\end{array}$ & $\begin{array}{l}\text { F-aA } \\
\stackrel{\times}{\text { E.c.t. }}\end{array}$ & $\begin{array}{l}\text { F-aE } \\
\stackrel{\times}{\times} \\
\text { A.c.t. }\end{array}$ & $\underset{\mathrm{F}-\mathbf{a A}}{\mathbf{a A}}$ & $\begin{array}{c}\mathrm{aE} \\
+ \\
\mathrm{F}-\mathrm{aE}\end{array}$ & \\
\hline 1 to 6 & + & + & - & + & - & + & - & - & \multirow{2}{*}{$\begin{array}{l}\text { Dermo-epidermal } \\
\text { boundary } \\
\text { membrane }\end{array}$} \\
\hline 21 to 28 & + & + & + & - & + & - & - & - & \\
\hline 2,6 & + & + & - & + & - & + & - & - & \multirow{2}{*}{$\begin{array}{l}\text { Dermal } \\
\text { mesenchymal } \\
\text { cells }\end{array}$} \\
\hline $1,3,4,5$ & - & + & - & + & - & + & - & - & \\
\hline $21,24,25$ & - & + & - & + & - & + & - & - & \multirow{4}{*}{ Dermal fibrils } \\
\hline $22,27,28$ & + & + & - & + & - & + & - & - & \\
\hline 23 & + & + & + & - & + & - & - & - & \\
\hline 26 & + & - & + & - & + & - & - & - & \\
\hline \multicolumn{5}{|c|}{$\begin{array}{l}\text { Embryos } 1 \text { to } 6 \text { comprised the } 1.0 \text { to } 1.5 \mathrm{~cm} \text {. group. } \\
\text { Embryos } 21 \text { to } 28 \text { comprised the } 1.5 \text { to } 2.0 \mathrm{~cm} \text {. group. } \\
\text { NRG }=\text { Normal rabbit globulin. } \\
\begin{array}{ll}\text { aA } & =\text { anti-Adult rat renal connective tissue antisera. }\end{array}\end{array}$} & $\begin{array}{l}\text { aE } \\
\text { E.c.t. } \\
\text { A.c.t. }\end{array}$ & \multicolumn{4}{|c|}{$\begin{array}{l}=\text { anti-Embryonic rat connective tissue antisera. } \\
=\text { Fluorescein label. } \\
=\text { Embryonic connective tissue. } \\
=\text { Adult renal connective tissue. }\end{array}$} \\
\hline
\end{tabular}




\section{(1) Adult Rat Kidney}

(a) Staining in Renal Glomeruli and the Media of Arteries.-The F-anti-adult conjugate produced a more complex pattern of staining in glomerular tufts than the F-anti-embryo conjugate did (Figs 1 and 2). Glomerular tufts in F-anti-adult stained sections showed specific fluorescence of the capillary basement membranes and of oval, polygonal, or crescentic extracapillary bodies (Fig. 3). These bodies were taken to represent glomerular epithelial cells. The F-anti-embryo conjugate did not react with the basement membranes of glomerular capillaries; staining produced by this conjugate in renal glomeruli appeared to be confined to the epithelial cells (Fig. 4).

The F-anti-adult conjugate produced specific staining, distributed either as a reticulate network or

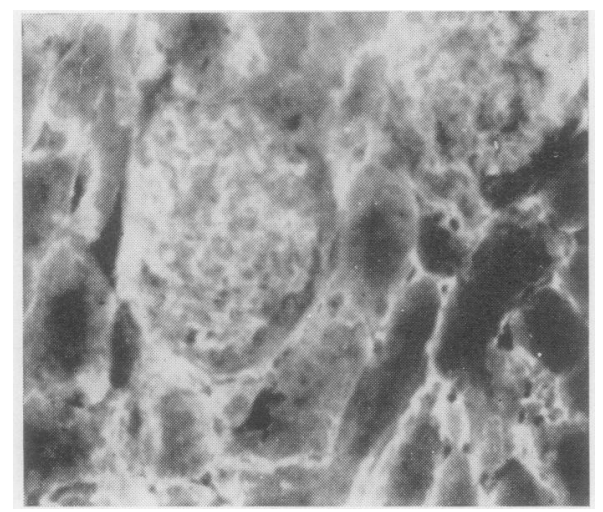

Fig. 1.-Adult rat kidney stained with F-anti-adult connective tissue conjugate. Specific staining in tubular basement membranes and in glomerular capillary tuft. Monochrome print from colour transparency. Enlarged $\times 2.5$ from $\times 160$.

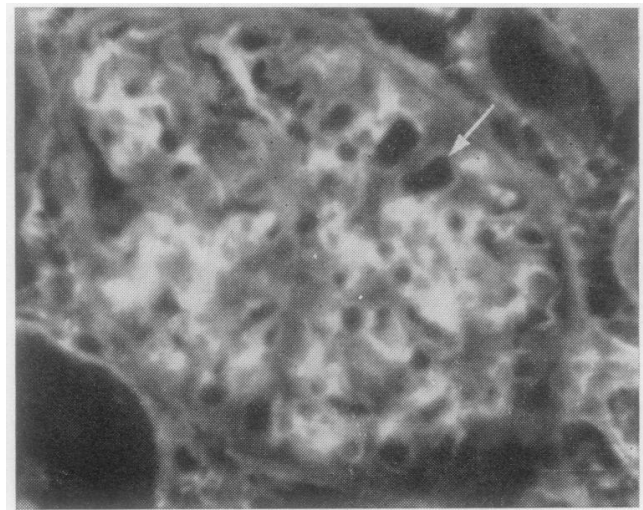

Fig. 3.-Glomerulus in adult rat kidney stained with F-anti-adult connective tissue conjugate. Specific staining in glomerular epithelial cells and in basement membranes of glomerular capillaries (arrowed). Enlarged $\times 2.8$ from $\times 240$. as a series of concentric lamellae in the media of arteries (Fig. 5, opposite).

The F-anti-embryo conjugate produced no staining in the media of arteries (Fig. 6, opposite).

(b) Staining in Tubular Basement Membranes.The F-anti-adult and F-anti-embryo conjugates appeared to differ also in their reactions with the tubular basement membranes in the kidneys of adult rats (Table III). In F-anti-adult stained sections, tubular basement membranes were usually seen as a single layer of brightly-stained material. Occasionally, however, this layer was seen to split to enclose a small spindle-shaped unstained space, and it was possible to resolve the membrane on either side of the split into two components (Fig. 7, opposite). This splitting and reduplication of tubular basement

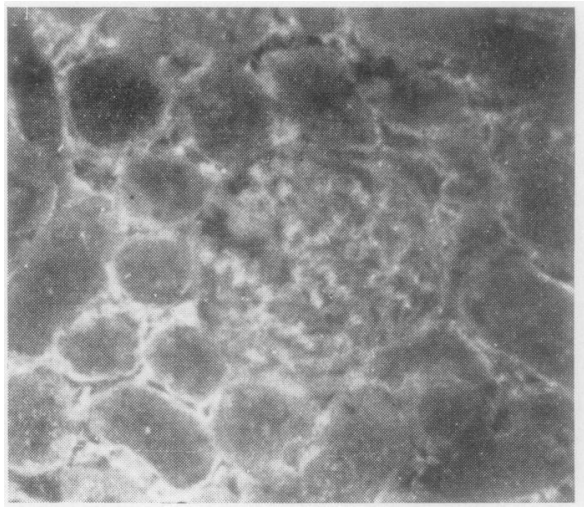

Fig. 2.-Adult rat kidney stained with F-anti-embryonic connective tissue conjugate. Staining in renal glomerular capillary tuft presents a less complex pattern than that produced by $\mathbf{F}$-anti-adult conjugate. Enlarged $\times 4.5$ from $\times 90$.

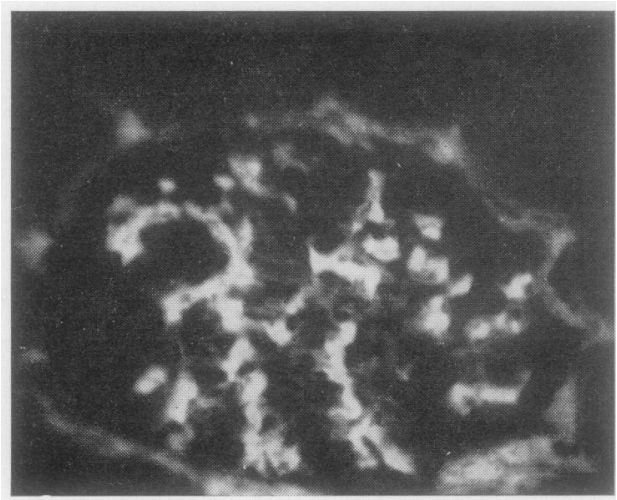

Fig. 4.-Renal glomerulus stained with F-anti-embryonic connective tissue conjugate. Specific staining confined to epithelial cells. Enlarged $\times 2 \cdot 0$ from $\times 320$. 


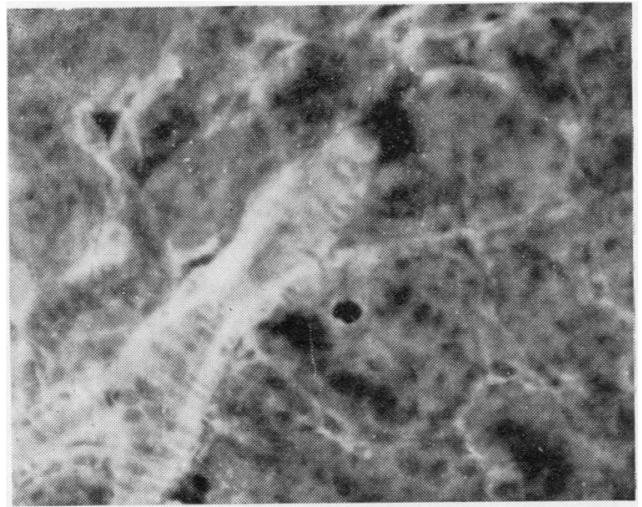

Fig. 5.-Specific staining in media of a renal artery produced by F-anti-adult connective tissue conjugate. Enlarged $\times 3$ from $\times 160$.

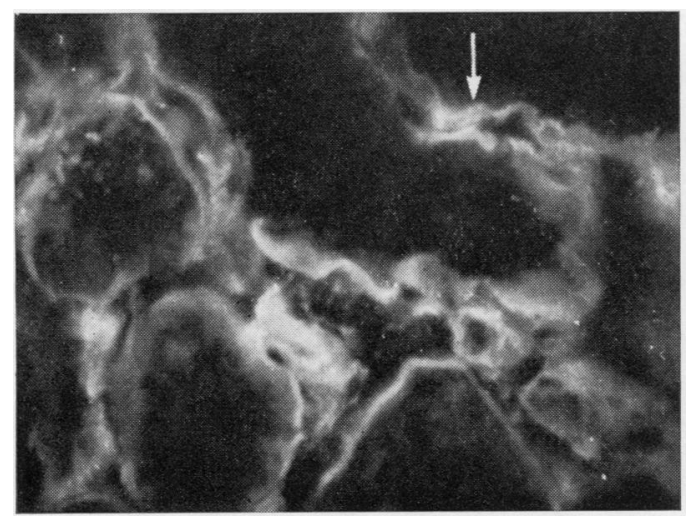

Fig. 7.-Unstained areas and splits (arrowed) in renal tubular basement membranes stained with F-anti-adult connective tissue conjugate. Enlarged $\times 3$ from $\times 300$.

membranes was not seen in F-anti-embryo stained sections.

(c) Staining in Renal Interstitial Tissue.-The F-anti-adult and the F-anti-embryo conjugates both reacted with material lying between renal tubules (Table III). The amount of renal interstitial tissue detected by the two conjugates varied from kidney to kidney. In some cases none was seen, in others the intertubular spaces contained a number of fine fibrils which appeared to fuse with tubular basement membranes (Fig. 8.)

\section{(2) Embryonic RAT SKIN}

(a) Dermo-epidermal Boundary Membranes.The F-anti-adult and F-anti-embryo conjugates each produced specific staining at the dermo-epidermal

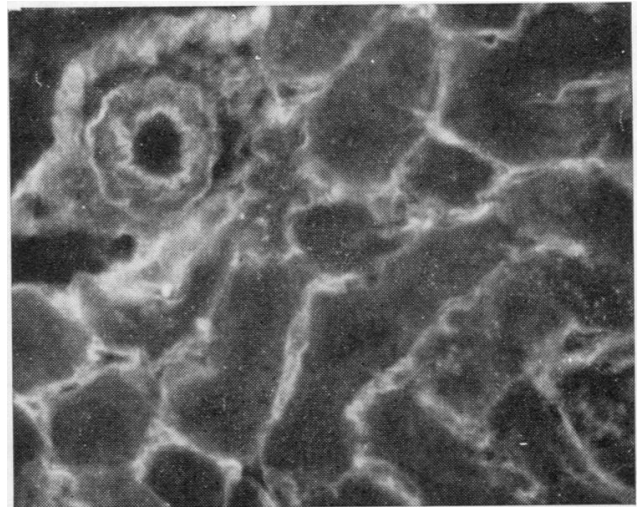

Fig. 6.-Adult rat kidney stained with F-anti-embryonic connective tissue conjugate. The artery shows auto-fluorescence of its elastic lamina; its media is unstained. Enlarged $\times 3$ from $\times 120$.

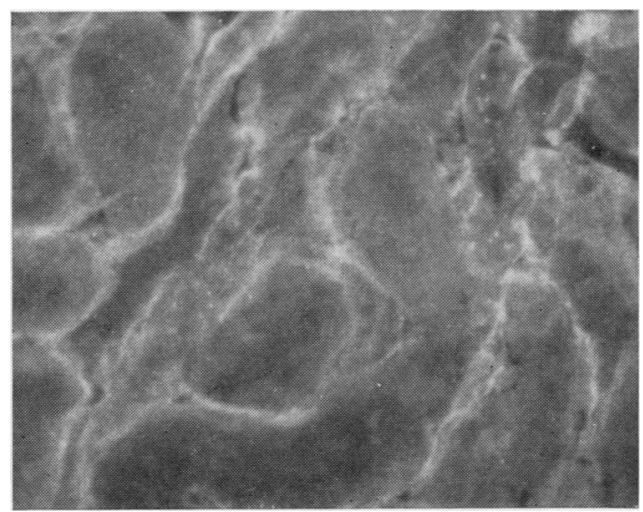

Fig. 8.-Specific staining of interstitial tissue and tubular basement membranes in adult rat kidney stained by $F$-anti-embryonic connective tissue conjugate. Enlarged $\times 3$ from $\times 160$.

junction in sections from both groups of rat embryos-those measuring between 1.0 and $1.5 \mathrm{~cm}$. and those measuring between 1.5 and $2.0 \mathrm{~cm}$. in crown to rump length (Figs 9 and 10, overleaf).

(b) Dermal Tissues.-The dermis of all embryos examined showed specific staining on exposure to one or other, or both of the two conjugates. In the case of the 1.0 to $1.5 \mathrm{~cm}$. embryos, specific staining had a cellular or pericellular distribution (Fig. 9), while in the dermis of the larger 1.5 to $2.0 \mathrm{~cm}$. embryos, specific staining had a fibrillar rather than a cellular distribution (Fig. 10).

When the results of F-anti-embryo and F-antiadult direct staining experiments were compared, it became evident that differences existed between embryos as regards the affinity shown by their dermal 


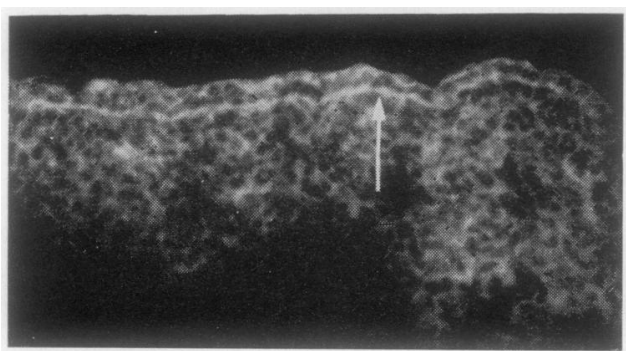

Fig. 9.-Skin of $1.4 \mathrm{~cm}$. rat embryo stained with F-anti-embryonic connective tissue conjugate. Staining of dermo-epidermal junction (arrowed) and in dermis. Staining in dermis has a cellular or pericellular distribution. The peripheral layer of the epidermis shows cellular distribution. The peripheral layer of the epidermis shows
non-specific staining. Monochrome print from colour transparency. Enlarged $\times 2 \cdot 5$ from $\times 160$.

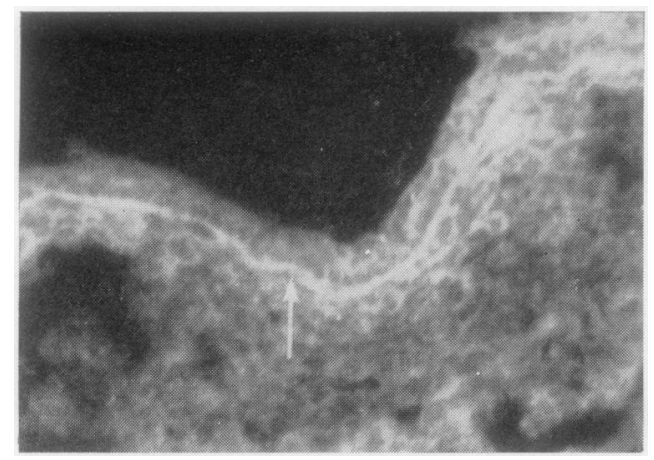

Fig. 10.-Skin of $2.0 \mathrm{~cm}$. rat embryo stained with F-anti-adult connective tissue conjugate. Fibrillar distribution of specific staining in dermis. The dermo-epidermal boundary membrane (arrowed) shows specific staining and the epidermis non-specific staining. Monochrome print from colour transparency. Enlarged $\times 3$ from $\times 120$.

tissues for antibodies present in the F-anti-embryo conjugate on the one hand, and in the F-anti-adult conjugate on the other (Table IV). Dermal mesenchymal cells in four of the smaller, and dermal fibrils in three of the larger embryos, appeared to contain antigens reactive with antibodies present only in the F-anti-embryo conjugate. Of the remaining seven embryos, sections from two 1.0 to $1.5 \mathrm{~cm}$. and from four 1.5 to $2.0 \mathrm{~cm}$. embryos showed specific dermal fluorescence on exposure to each of the conjugates, while one of the 1.5 to 2.0 $\mathrm{cm}$. embryos contained dermal fibrils reactive with antibodies only in the F-anti-adult conjugate.

\section{Cross-Inhibition Experiments}

In cross-inhibition experiments, conjugates of the one specificity were reacted with sections in the presence of unlabelled immune globulins of the other specificity (Table II).

\section{(1) Adult Rat Kidney}

Observations arising out of cross-inhibition experiments on sections of adult rat kidney are summarized in Table III.

Unlabelled globulin fractions of anti-adult rat renal connective tissue antisera brought about complete inhibition of the staining normally produced by the F-anti-embryo conjugate in sections from the kidneys of adult rats.

In anti-embryo + F-anti-adult cross inhibition experiments renal interstitial tissue remained unstained, but staining appeared in the media of arteries, in the basement membranes of renal tubules, and in glomerular capillaries (Fig. 11).

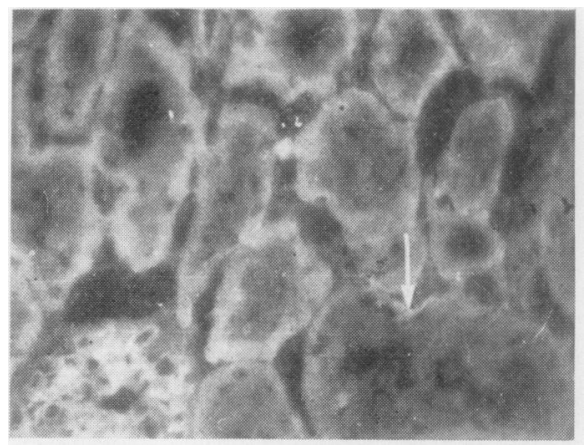

Fig. 11.-Adult rat kidney stained by $\mathrm{F}$-anti-adult connective conjugate in presence of unlabelled anti-embryonic connective tissue antiserum globulins. Specific staining of glomerular capillary basement membranes and fine faint staining of tubular basement membranes (arrowed). Enlarged $\times 2$ from $\times 120$.

Tubular basement membranes in sections submitted to the cross-inhibition procedure, however, were less brightly stained and appeared to be finer than the membranes seen in sections stained by the normal rabbit globulin + F-anti-adult direct staining procedure. Glomerular capillary loops presented a crisper pattern of staining after cross-inhibition than they did after direct staining experiments. In crossinhibition experiments, glomerular staining appeared to be confined to the basement membranes of capillaries, whereas in direct staining experiments glomeruli showed specific staining of capillary basement membrane and epithelium.

\section{(2) EMBRYonic RAT SKIN}

(a) 1.0 to $1.5 \mathrm{~cm}$. Rat Embryos.-Although the dermo-epidermal boundary membranes in sections from all 1.0 to $1.5 \mathrm{~cm}$. embryos and dermal mesenchymal cells in sections from two of these embryos showed specific staining in both sets of direct staining experiments (Table IV), unlabelled globulin fractions of anti-adult rat connective tissue antisera did not prevent the F-anti-embryo conjugate from staining 
these structures in anti-adult $+\mathrm{F}$-anti-embryo crossinhibition experiments. The unlabelled anti-embryonic connective tissue globulins, however, blocked all the staining normally produced by the F-antiadult conjugate in the skin of 1.0 to $1.5 \mathrm{~cm}$. rat embryos.

(b) 1.5 to $2.0 \mathrm{~cm}$. Rat Embryos.-While unlabelled anti-adult globulins did not prevent the F-anti-embryo conjugate from staining the epidermal boundary membranes in sections from 1.0 to $1.5 \mathrm{~cm}$. rat embryos, they did block all interaction between the F-anti-embryo conjugate and the dermoepidermal boundary membrane in the skin of 1.5 to $2.0 \mathrm{~cm}$. rat embryos (Table IV).

It has been predicted that no dermal staining would appear in cross-inhibition experiments in sections from the four 1.5 to $2.0 \mathrm{~cm}$. embryos, which had shown dermal fibrillar staining in normal rabbit globulin $+\mathrm{F}$-anti-adult and in normal rabbit globulin + F-anti-embryo direct staining experiments. In the event, however, one of these embryos (No. 23, Table IV) showed dermal fibrillar staining in anti-embryo + F-anti-adult experiments, but not in anti-adult + F-anti-embryo experiments, and three (Nos 22, 27, and 28, Table IV) showed dermal fibrillar staining in the anti-adult + F-anti-embryo experiments.

\section{Cross-Absorption Experiments}

(1) F-Anti-Adult $\times$ Embryonic Connective Tissue

The cross-absorbed F-anti-adult $\times$ embryo conjugates produced no staining in the dermis or the dermo-epidermal boundary membranes of 1.0 to $1.5 \mathrm{~cm}$. rat embryos, but this conjugate was found to have lost only some, not all, of its reactivity for connective tissues in the skin of 1.5 to $2.0 \mathrm{~cm}$. rat embryos and in the kidneys of adult rats.

The cross-absorbed F-anti-adult conjugate produced specific fluorescence at the dermo-epidermal boundary membrane in the skin of all 1.5 to $2 \cdot 0 \mathrm{~cm}$. rat embryos, and stained dermal fibrils in two of these embryos (Nos 23 and 26, Table IV). Thus, the pattern of reactivity shown by embryonic dermal tissue in F-anti-adult $\times$ embryonic connective tissue cross-absorption experiments was similar to that shown by these tissues in anti-embryo + F-antiadult cross-inhibition experiments.

Similarly, in the case of the kidneys of adult rats, the distribution of staining seen after cross-absorption experiments paralleled that seen after crossinhibition experiments. That is to say, the crossabsorbed F-anti-adult $\times$ embryo conjugate stained the basement membranes of renal glomerular capillaries and the media of arteries, and produced fine fluorescence in the position of renal tubular basement membranes, but did not react with renal interstitial tissue nor with glomerular epithelial cells.

(2) F-anti-Embryo $\times$ Adult Connective Tissue The cross-absorbed F-anti-embryo $\times$ adult conjugate produced no staining in sections cut from the kidneys of adult rats (Table III), and was found to have lost all reactivity for dermo-epidermal boundary membranes in 1.5 to $2.0 \mathrm{~cm}$. rat embryos. This conjugate, however, continued to react with the dermo-epidermal boundary membranes and dermal mesenchymal cells in the skin of 1.0 to $1.5 \mathrm{~cm}$. rat embryos (Table IV).

Sections from six of the eight 1.5 to $2.0 \mathrm{~cm}$. embryos examined showed dermal fibrillar staining in $\mathrm{F}$-anti-embryo $\times$ adult cross-absorption experiments. Three of these sections were derived from embryos possessing dermal fibrils reactive in direct staining experiments only with the F-anti-embryo conjugate (embryos Nos 21, 24, and 25, Table IV). Dermal tissues of the remaining three embryos (Nos 22,27 , and 28) had been found to show fibrillar staining in both sets of direct staining experiments, but only in one of the two groups of cross-inhibition experiments-the anti-adult + F-anti-embryo experiments.

\section{Discussion}

Connective tissues in the skin of embryonic rats exhibited four patterns of reactivity in the present series of direct staining, cross-inhibition, and crossabsorption immuno-histological experiments. These patterns are considered in terms of their possible implications in Table $\mathrm{V}$ (overleaf). They have been taken to mean that the following three groups of connective tissue antigens occurred in varying concentration in the epidermal boundary membranes and the dermis of rat embryos:

\section{(a) Adult Antigens}

Antigens reactive with antibodies present only in antisera raised against renal connective tissues obtained from adult rats.

\section{(b) Embryonic Antigens}

Antigens reactive with antibodies detectable only in anti-embryonic connective tissue antisera.

\section{(c) Common Antigens}

Antigens reactive with antibodies present in antiadult and in anti-embryonic rat connective tissue antisera. 
TABLE V

STAINING REACTIONS SHOWN BY CONNECTIVE TISSUES IN THE SKIN

OF RAT EMBRYOS MEASURING (a) LESS THAN AND (b) MORE THAN $1.5 \mathrm{~cm}$. IN CROWN TO RUMP LENGTH

\begin{tabular}{|c|c|c|c|c|c|c|c|c|}
\hline \multirow{3}{*}{$\begin{array}{c}\text { Tissue } \\
\text { Component }\end{array}$} & \multirow{3}{*}{ Embryo No. } & \multicolumn{6}{|c|}{ Staining Experiment } & \multirow{3}{*}{ Antigens Present } \\
\hline & & \multicolumn{2}{|c|}{$\begin{array}{c}\text { Direct } \\
\text { Staining }\end{array}$} & \multicolumn{2}{|c|}{$\begin{array}{c}\text { Cross- } \\
\text { Inhibition }\end{array}$} & \multicolumn{2}{|c|}{$\begin{array}{c}\text { Cross- } \\
\text { Absorption }\end{array}$} & \\
\hline & & $\begin{array}{c}\text { NRG } \\
+ \\
\text { F-aA }\end{array}$ & $\begin{array}{c}\text { NRG } \\
+ \\
\text { F-aE }\end{array}$ & $\begin{array}{c}\mathrm{aE} \\
+ \\
\mathrm{F}-\mathrm{aA}\end{array}$ & $\begin{array}{c}\mathrm{aA} \\
+ \\
\mathrm{F}-\mathrm{aE}\end{array}$ & $\begin{array}{l}\text { F-aA } \\
\times \\
\text { E.c.t. }\end{array}$ & $\begin{array}{l}\mathrm{F}-\mathrm{aE} \\
\stackrel{\times}{\times} \\
\text { A.c.t. }\end{array}$ & \\
\hline \multirow{4}{*}{ Dermis } & 26 & + & - & + & - & + & - & Adult \\
\hline & 23 & + & + & + & - & + & - & Adult and Common \\
\hline & $2,6,27,28$ & + & + & - & + & - & + & Embryonic and Common \\
\hline & $\begin{array}{l}1,3,4,5 \\
21,24,25\end{array}$ & - & + & - & + & - & + & Embryonic \\
\hline \multirow{2}{*}{ DEJ } & 1 to 6 & + & + & - & + & - & + & Embryonic and Common \\
\hline & 21 to 28 & + & + & + & - & + & - & Adult and Common \\
\hline
\end{tabular}

Embryos 1 to $6: 1.0$ to $1.5 \mathrm{~cm}$. group. aA $=$ anti-Adult rat renal connective tissue. $\mathrm{F}=$ Fluorescein label.

Embryos 21 to $28: 1.5$ to $2 \cdot 0 \mathrm{~cm}$. group. aE $=$ anti-Embryonic rat connective tissue. DEJ $=$ Dermo-epidermal boundary membrane.

Adult antigens were found in the dermo-epidermal boundary membranes of all of the 1.5 to $2 \cdot 0 \mathrm{~cm}$. rat embryos and in the dermis of two of them. In the epidermal boundary membranes adult antigens were found in association with common antigens and in the dermis they were present either alone (embryo 26) or in association with common antigens (embryo 23). Adult antigens were not detected in the dermis or epidermal boundary membranes of the smaller 1.0 to $1.5 \mathrm{~cm}$. embryos. Embryonic antigens, on the other hand, were found in the dermis of both groups of embryos. They were the only group of connective tissue antigens detected in the dermis of four of the smaller embryos $(1,3,4$, and 5) and of three of the larger embryos $(21,24$, and 25). Embryonic antigens were found together with common antigens in the epidermal boundary membranes of all of the 1.0 to $1.5 \mathrm{~cm}$. embryos, in the dermis of four of these, and in the dermis of the 1.5 to $2.0 \mathrm{~cm}$. embryos 22 , 27 , and 28.

Pertinent to the present findings that the antigenic properties of dermal and juxta-epidermal connective tissues in the skin of rat embryos differ between embryos, or groups of embryos, are the observations of Eroshkina and Kolymykova (1960). These workers found that the antigenic properties of human connective tissues changed during growth in tissue culture, so that antigens characteristic of embryonic tissues were partially lost and those characteristic of adult tissues acquired. These observations raise the possibility that an ordered sequence of change occurs in the antigenic properties of connective tissue during embryonic life.
Taylor, Shepherd, and Robertson (1961), in an immuno-histological study of granulation tissue, found that antisera raised against renal glomeruli and pulmonary tissue from adult rats reacted with a wide variety of connective tissues, including argyrophilic reticulum, in the adult rat, but did not react with argyrophilic fibrils in young granulation tissue. This observation, taken together with the findings of Eroshkina and Kolymykova, raises the possibility that the developmental history of connective tissue may be recapitulated during repair. A phenomenon of this nature may have implications for human disease. In certain individuals repair may be associated with the appearance of tissues unusually susceptible to bacterial or viral attack, or with the re-appearance of antigens to which immunological tolerance has been lost.

\section{Summary}

Antisera raised against renal connective tissues obtained from adult rats and those raised against embryonic rat connective tissues were found to exhibit differences as well as similarities in their antitissue specificities when reacted in direct staining, cross-inhibition, and cross-absorption immunohistological staining experiments with the kidneys of adult rats and the skin of rat embryos measuring from 1.0 to $1.5 \mathrm{~cm}$. and from 1.5 to $2.0 \mathrm{~cm}$. in crown to rump length. It was also found that differences existed between embryos, and groups of embryos, as regards the antigenic properties of their dermal and juxta-epidermal connective tissues. These observations have been interpreted as meaning that changes occur in the antigenic constitution of 
embryonic connective tissues during development, and the possible implications these findings may have for diseases in man are briefly discussed.
We wish to thank Mr. R. A. Forster for the preparation of the illustrations. We are indebted to the Arthritis and Rheumatism Council for financial support.

\section{REFERENCES}

Eroshkina, A. M., and Kolymykova, V. N. (1960). Bull. exp. Biol. and Med. U.S.S.R., 49, 406 (Eng. ed.) (Some peculiarities in the antigenic properties of human embryonic tissues when cultured on various media). Abstr. in Collagen Currents (1961), 1, No. 9 (March), p. 25, Abstr. No. 1-448.

Hill, A. G. S., and Cruickshank, B. (1953). Brit. J. exp. Path., 34, 27 (A study of antigenic components of kidney tissue).

Krakower, C. A., and Greenspon, S. A. (1951). Arch. Path., 51, 629 (Localization of the nephrotoxic antigen within the isolated renal glomerulus).

Scott, D. G., and Rowell, N. R. (1967). Ann. rheum. Dis., 26, 10 (Alterations in the antigenic constitution of renal glomerular capillaries accompanying the histological maturation of renal glomeruli in the rat).

Taylor, H. E., Shepherd, W. E., and Robertson, C. E. (1961). Amer. J. Path., 38, 39 (An immunohistochemical examination of granulation tissue with glomerular and lung antiserums).

Les altérations des propriétés antigéniques des tissus conjonctifs de la peau des rats embryonnaires en cours de leur développement

\section{RÉSUMÉ}

Les anti-sérums préparés contre le tissu conjonctif rénal des rats adultes et ceux préparés contre le tissu conjonctif embryonnaire de ces animaux accusèrent des differences mais aussi des similarités en leurs spécifités anti-tissulaires, lorsqu'on les fit réagir-sous coloration directe, inhibition croisée et coloration immuno-histologique avec absorption croisée-avec les reins des rats adultes et les peaux des rats embryonnaires de 1 à $1,5 \mathrm{~cm}$. et de 1,5 à $2 \mathrm{~cm}$. de longueur. On trouva aussi des différences entre des embryons et des groupes d'embryons à l'égard des propriétés antigéniques de leurs tissus conjonctifs dermique et juxta-épidermique. Ces observations suggèrent qu'il se produisent des altérations de la constitution antigénique du tissu conjonctif au cours du développement embryonnaire. On discute brièvement les implications possibles de ces résultats dans les maladies humaines.
Las alteraciones de las propiedades antigénicas de los tejidos conectivos de la piel de ratas embrionarias en el curso de su desarrollo

\section{Sumario}

Los antisueros preparados contra el tejido conectivo renal de las ratas adultas y otros preparados contra el tejido conectivo embrionario de estos animales acusaron tanto diferencias como similitudes en sus especifidades contra los tejidos en reacción-en experimentos de tinción directa, inhibicion cruzada y tinción inmunohistológica con absorpción cruzada-con riñones de ratas adultas y pieles de ratas embrionarias de 1 a $1,5 \mathrm{~cm}$. y de $1,5 \mathrm{~cm}$. a $2 \mathrm{~cm}$. de tamaño. Se observaron también diferencias entre embrios y grupos de embrios respecto a propiedades antigénicas de sus tejidos conectivos dérmico y yuxta-epidérmico. La interpretación de estas observaciones indica la existencia de alteraciones de la constitución antigénica del tejido conectivo durante su desarrollo embrionario. Se discuten brevemente las implicaciones posibles de estos resultados en enfermedades humanas. 